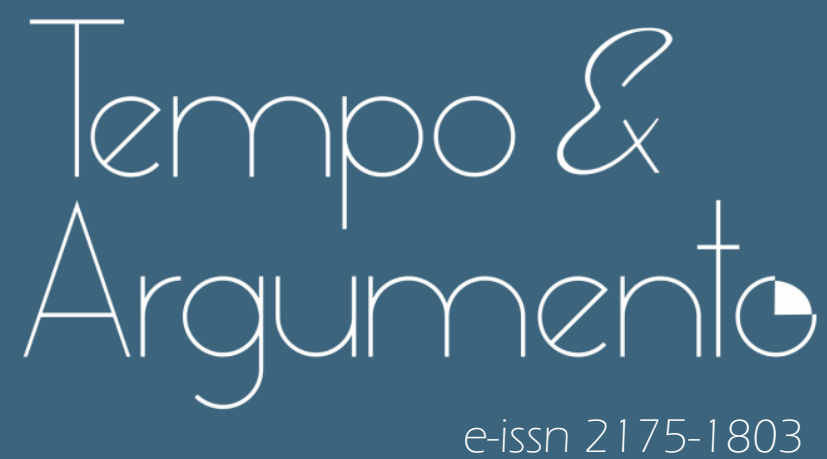

\title{
A guerra de Nagorno-Karabakh: as disputas em torno dos conceitos de 'vítima' e 'genocídio' no tempo presente
}

- Heitor de Andrade Carvalho Loureiro

Doutor em História pela Universidade Estadual Paulista Júlio de Mesquita Filho (UNESP).

Pesquisador associado do Grupo de Estudos e Pesquisa sobre o Oriente Médio (Gepom).

São Paulo, SP - BRASIL

lattes.cnpq.br/4208395150191646

heitorloureiro@gmail.com

(iD) orcid.org/0000-0001-8378-8232

- Pedro Bogossian Porto

Doutor em Antropologia pela Universidade de Paris.

Pesquisador associado da Unité de Recherche Migration et Sociétés (URMIS)

Paris - FRANÇA

lattes.cnpq.br/2479403453248935

pedro_bogo@yahoo.com.br

(iD) orcid.org/0000-0002-0506-7728

Para citar este artigo:

LOUREIRO, Heitor; PORTO, Pedro Bogossian. A guerra de Nagorno-Karabakh: as disputas em torno dos conceitos de 'vitima' e 'genocídio' no tempo presente.

Tempo e Argumento, Florianópolis, v. 13, n. 32, e0 11 1, jan./abr. 2021.

http://dx.doi.org/10.5965/2175180313322021 e0111 


\title{
A guerra de Nagorno-Karabakh: as disputas em torno dos conceitos de 'vítima' e 'genocídio' no tempo presente
}

\begin{abstract}
Resumo
O presente artigo tem como finalidade analisar a noção de "vítima" e os usos do conceito de "genocídio" envolvendo armênios e azerbaijanos na guerra de Nagorno-Karabakh. O objetivo é compreender como ambos os povos mobilizam essas noções de forma a sustentar suas reivindicações políticas sobre o território em questão e deslegitimar as aspirações do outro. Nesse sentido, é crucial compreender os usos políticos dos massacres e genocídios na tentativa de angariar apoio internacional para suas causas. Para tanto, vamos analisar posicionamentos de lideranças armênias e azerbaijanas sobre o conflito descongelado em setembro de 2020.
\end{abstract}

Palavras-chave: Armênia. Azerbaijão. Nagorno-Karabakh. Guerra. Genocídio.

\section{The Nagorno-Karabakh war: disputes over the concepts of 'victim' and 'genocide' in the present time}

\begin{abstract}
This article aims at analyzing the idea of 'victim' and the uses of the concept of 'genocide' involving Armenians and Azerbaijanis in the Nagorno-Karabakh conflict. How do the parties mobilize these ideas in order to sustain their political demands regarding that territory and to delegitimize the aspirations of the other? The political leveraging of massacres and genocides for the purpose of raising international support for a cause is important to understand in this regard. We analyze the positions of Armenian and Azerbaijani leaders on the unfrozen conflict between September 27 to November 10, 2020.
\end{abstract}

Keywords: Armenia. Azerbaijan. Nagorno-Karabakh. War. Genocide.

\section{Introdução}

Aghdam é uma cidade na fronteira da autoproclamada República de Artsakh - Nagorno-Karabakh11 - com o Azerbaijão. Nos anos 1980, a cidade era povoada majoritariamente por azerbaijanos. Em fevereiro de 1988, a população

\footnotetext{
' Нагорный Карабах (Nagorny Karabakh, em russo, o nome pelo qual a região é internacionalmente

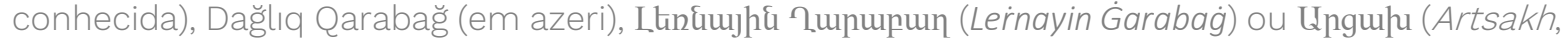
em armênio). Muitas localidades mencionadas neste capítulo têm diferentes nomes de acordo com a língua tomada como referência. Frequentemente, a opção por um topônimo e não outro revela uma escolha política. Portanto, ao longo deste texto, sempre que necessário, a toponímia será acompanhada de uma nota com os demais nomes pelos quais a localidade é conhecida em diferentes culturas.
} 
A guerra de Nagorno-Karabakh: as disputas em torno dos conceitos de 'vítima' e 'genocídio'

de Aghdam recebeu a notícia de que os armênios de Nagorno-Karabakh principalmente na capital, Stepanakert, a 25 km de distância - iniciavam um protesto. Até aquele momento, a Oblast - região - Autônoma de NagornoKarabakh², embora tivesse uma população majoritariamente armênia, era controlada pela República Socialista Soviética do Azerbaijão, à qual fora anexada em 1923. Os manifestantes exigiam que o controle da região fosse transferido à República Socialista Soviética da Armênia, de modo a fazer coincidir composição étnica e estrutura política.

Descontentes com a crise econômica e política generalizada na URSS no final dos anos 1980, os azerbaijanos de Aghdam e de outras cidades da região se sentiram traídos pela demanda armênia e organizaram diversas manifestações em resposta. Essa insatisfação levou um grupo de azerbaijanos a partir, em fevereiro de 1988, de Aghdam em direção à cidade vizinha, Askeram, habitada majoritariamente por armênios. O grupo de azerbaijanos foi recebido a tiros pelos armênios, que viram na marcha uma ameaça. Dois azerbaijanos teriam morrido, o que provocou uma série de revoltas em todo o Azerbaijão Soviético. Com o enfraquecimento do poder central em Moscou, as revoltas se tornavam cada vez mais violentas e elevava-se o grau de tensão entre as populações (LIBARIDIAN, 2004). Assim, dias depois do enfrentamento em Askeram, novas manifestações eclodiram na cidade de Sumgait, nos arredores de Baku, onde os protestos cresceram a ponto de se transformarem em um pogrom antiarmênio. O episódio terminou com cerca de 30 armênios mortos e centenas de feridos (DE WAAL, 2003, p. 32-33).

\footnotetext{
${ }^{2}$ O artigo 24 da Constituição Soviética de 1936 dispõe que "A República Socialista Soviética do Azerbaijão inclui a República Socialista Soviética Autônoma de Nakhichevan e a Região [em russo, oblast] Autônoma de Nagorno-Karabakh". Considerando a qualidade do poder, a soberania é a condição de supremacia que caracteriza a União das Repúblicas Socialistas Soviéticas, isto é, o próprio Estado soberano. A organização político-administrativa da URSS prevê, do geral para o específico, as Repúblicas Socialistas Soviéticas (como Rússia, Ucrânia, Armênia, Azerbaijão etc.), as Repúblicas Socialistas Soviéticas Autônomas (como Nakhichevan, Moldávia, Abkhazia, Daguestão etc.) e as Regiões Autônomas (como Nagorno-Karabakh, Chechênia, Ossétia do Norte etc.). O status de alguns desses territórios foi alterado ao longo da história da URSS: "Às vésperas da perestroika, por exemplo, havia vinte repúblicas autônomas, oito regiões autônomas e dez áreas autônomas na URSS” (SEGRILLO, 2000, P. 159). Cf. também CONSTITUTION OF THE UNION OF SOVIET SOCIALIST REPUBLICS Adopted at the Extraordinary Eighth Congress of Soviets of the U.S.S.R. December 5, 1936. https://constitutii.files.wordpress.com/2013/01/1936-en.pdf, acesso em 19 mar. 2021.
} 
A guerra de Nagorno-Karabakh: as disputas em torno dos conceitos de 'vítima' e 'genocídio' no tempo presente

Heitor Loureiro, Pedro Bogossian Porto

Quando a Guerra de Nagorno-Karabakh foi deflagrada, no começo dos anos 1990, Aghdam tinha uma posição estratégica, uma vez que ela se situa muito próximo a cidades importantes como Askeran, Khojaly e Stepanakert, capital da então Oblast Autônoma de Nagorno-Karabakh. Aghdam também era passagem rodoviária importante ligando Nagorno-Karabakh à capital azerbaijana Baku.

As tensões em torno de Aghdam se intensificaram a partir de 1993, quando os armênios acusaram o Azerbaijão de instalar baterias de mísseis em áreas residenciais da cidade. Dali, o Azerbaijão bombardearia, frequentemente, as cidades ao redor, e seria capaz de atingir a capital, Stepanakert. Assim, na tentativa de neutralizar as baterias azerbaijanas, os armênios atacaram e destruíram parte da cidade. Considerada essencial para o controle da região, Aghdam era reconhecida como uma cidade azerbaijana ocupada estrategicamente pelas forças de defesa de Nagorno-Karabakh. Os azerbaijanos alegam que os armênios teriam destruído a cidade muito mais do que o militarmente necessário, com o intuito de desencorajar o retorno da população que ali vivia. A destruição da cidade forçou um grande número de azerbaijanos de Aghdam a se deslocar para Baku, onde, desde então, eles vivem em situação precária - em nítido contraste com a riqueza da capital do país.

Outro objeto de protestos azerbaijanos foi a suposta destruição de patrimônio histórico e arquitetônico da cidade. Um dos únicos prédios que permaneceram de pé após a captura de Aghdam pelas forças armênias foi a mesquita da cidade, construída no século XIX. Embora o governo de NagornoKarabakh tenha se comprometido a fazer a manutenção do local - assim como de outras mesquitas e monumentos da cultura azerbaijana na região - Baku periodicamente contesta, desde o cessar-fogo de 1994, a eficácia das ações de preservação levadas a cabo pelas autoridades armênias.

A imagem da cidade, completamente destruída e abandonada, levou os jornalistas ocidentais que cobriam a guerra a descrevê-la como a "Hiroshima do Cáucaso", em referência à cidade japonesa após 1945³. Essa imagem foi utilizada

\footnotetext{
${ }^{3}$ Em tweet do dia 18 de novembro de 2020, o jornalista Thomas De Waal afirma que a alcunha de "Hiroshima do Cáucaso" a Aghdam foi dada por ele: "Hiroshima of the Caucasus was from me actually!" Twitter: @Tom_deWaal, 18 nov 2020. Disponível em: https://twitter.com/Tom_deWaal/status/1329001952311717890?s=20, acesso em: 22 nov 2020.
} 
pelo governo em Baku por ser clara e didática para o público ocidental, que rapidamente consegue relacionar a hecatombe nuclear na II Guerra com a destruição da cidade no Cáucaso. Com a vitória militar das forças armênias em 1994 e a proclamação de independência da República de Nagorno-Karabakh, o governo azerbaijano passou a explorar elementos da cultura do Azerbaijão que seriam oriundos de Nagorno-Karabakh. Um exemplo desse uso político do simbolismo em torno da cidade é o time de futebol Qarabağ, que originalmente mandava seus jogos em Aghdam. A equipe foi "adotada" pelo governo do Azerbaijão - recebendo aporte financeiro de uma empresa controlada pelo Estado - e pela população como um símbolo do que eles chamam de “ocupação” armênia de seu território.

A partir da constatação de que a Guerra de Nagorno-Karabakh desempenhou um papel central não apenas nos processos de independência da Armênia e do Azerbaijão, mas também na formação nacional desses dois países, pretendemos analisar o significado que o conflito possui atualmente para as duas populações envolvidas. No lado azerbaijano, a força simbólica dessa guerra se manifesta, por exemplo, na importância que o governo de Baku atribui ao time Qarabağ ou na ênfase que o massacre de Khojaly ${ }^{4}$ possui nas narrativas azerbaijanas sobre o embate. No lado armênio, essa mesma força simbólica pode ser percebida nas frequentes associações entre a Guerra de Nagorno-Karabakh e o genocídio da população armênia perpetrado pelo Império Otomano entre 1915 e 1923. Consideramos que a Guerra de Nagorno-Karabakh é, por um lado, um recurso crucial às autoridades de ambos os Estados para dar coesão à sua população e, por outro, que é empregada como fonte de legitimidade para os seus respectivos governos. Assim, a compreensão da importância que essa guerra possui na construção de um "imaginário nacional” ajuda a explicar a perenidade do conflito e a frequente eclosão de novas hostilidades.

Para melhor analisar as representações que armênios e azerbaijanos fazem da guerra será necessário, em um primeiro momento, observar a evolução histórica da disputa que as duas nações travam pela região. As origens dessa disputa remontam, ao menos, ao momento em que Armênia e Azerbaijão se

\footnotetext{
${ }^{4}$ Xocalı, em azerbaijano; Ivanyan (hцlu氏juu氏) em armênio.
} 
formaram enquanto Estados modernos, em 1918 - embora conflitos étnicos entre os dois grupos já tivessem ocorrido em 1905 e durante o século XIX. Assim, as narrativas a respeito da questão do Karabakh envolvem diferentes interpretações dos processos históricos experimentados no Cáucaso ao longo dos séculos XX e XXI: independência em relação ao Império Russo, dominação soviética e novos movimentos de independência, entre outros. A partir daí, será possível examinar de maneira mais cuidadosa os discursos produzidos por cada uma das duas populações.

A segunda parte será dedicada, portanto, às representações que os armênios fazem da Guerra de Nagorno-Karabakh e às frequentes associações entre essa guerra e o genocídio do início do século XX. A narrativa dos armênios sobre a guerra é permeada pela identificação de um inimigo "turco" e a vinculação do Azerbaijão à República da Turquia, herdeira do Império Otomano e que até hoje alimenta um discurso negacionista em relação ao genocídio perpetrado pelo império a partir de 1915. Assim, faz sentido analisar o conflito atual na chave de um tempo irrevogável, como elabora o historiador belga Berber Bevernage (2012, p. 2-3), segundo o qual o passado subsiste no tempo presente, ressignificando contendas históricas que, apesar de terem acontecido há muito tempo, ainda permanecem e afetam o presente e são fundamentais para a consolidação de identidades.

$\mathrm{Na}$ terceira parte, analisaremos as representações construídas pelos azerbaijanos a respeito das cidades e regiões perdidas na Guerra de NagornoKarabakh durante os anos 1990. Para tanto, o discurso proferido pelo presidente da República Itham Aliyev no dia 10 de novembro de 2020, quando do anúncio de um novo cessar-fogo na região, constitui um rico material de análise. A partir de sua leitura será possivel refletir sobre os usos da história para legitimar o emprego da força nos mais recentes confrontos e como o atual status quo representa uma vitória inexorável comandada pelo presidente, cumprindo assim uma espécie de "missão histórica" iniciada por seu pai, o presidente anterior.

A observação do conflito entre armênios e azerbaijanos e das narrativas a respeito da guerra torna nítido o papel central ocupado pela memória na construção das identidades coletivas dessas duas populações. Essa disputa no 
campo da memória serve de base, assim, a determinados projetos nacionais, o que corrobora as reflexões de Michel Pollak (1992) a esse respeito. Em outras palavras, o passado é reinterpretado e reescrito, instrumentalizado por ambos os lados no presente, o que mostra a clara imbricação de história e política e mantém sujeito e objeto na mesma temporalidade (FICO, 2012, p. 44).

Embora nossos objetos de investigação sejam as narrativas a respeito da Guerra de Nagorno-Karabakh, é importante destacar que não pretendemos propor aqui uma análise semiótica do discurso. Em vez disso, buscamos cotejar as "memórias divididas" (PORTELLI, 1998) com a bibliografia existente e com fontes variadas e difusas, de modo a melhor responder ao grande desafio que se impõe ao historiador do tempo presente. Assim, vamos analisar a forma como noções de "genocídio" e "vítima” foram empregadas por lideranças políticas e sociais - sejam armênias ou azerbaijanas, seja no Cáucaso ou na diáspora - no contexto das escaramuças entre os dois grupos no ano de 2020.

\section{A questão de Nagorno-Karabakh: um conflito na longa duração}

Entre a primeira metade do século XIX e a eclosão da Revolução Bolchevique na Rússia, em 1917, o sul do Cáucaso integrava o Império Russo, ao qual ele fora anexado após sucessivas vitórias sobre os impérios Persa e Otomano (MOURADIAN, 1986, p. 55). As relações entre armênios, azerbaijanos então designados como "tártaros do Cáucaso" -, georgianos e outros grupos étnicos que viviam na região eram então relativamente pacíficas, de tal maneira que as cidades de porte médio apresentavam grande heterogeneidade étnica. Esse era o caso, por exemplo, de Yerevan, que se tornaria a capital da Primeira República Armênia, onde a proporção de armênios não superava 60\% (TER MINASSIAN, 2006, p. 20). Ao mesmo tempo, Baku e Tiflis - hoje Tbilisi, atual capital da Geórgia - abrigavam grandes comunidades armênias, assim como outros grupos étnicos.

A agitação social provocada pela I Revolução Russa, em 1905, mudou, no entanto, a situação de relativa tranquilidade e marcou a escalada das tensões entre as diferentes etnias. Isso levou à eclosão da Guerra Armênio-Tártara 1905-1906 - marcada pelo enfrentamento em cidades como Baku, Shushi e 
A guerra de Nagorno-Karabakh: as disputas em torno dos conceitos de 'vítima' e 'genocídio' no tempo presente

Heitor Loureiro, Pedro Bogossian Porto

Gandzak. De acordo com depoimentos reproduzidos por Thomas de Waal (2003, p. 99), o conflito produziu centenas de mortos entre armênios e tártaros.

A progressiva contenção dos ataques diretos não reduziu a hostilidade entre os dois grupos, que voltaram a se enfrentar a partir de 1918. Com o Império Russo em acelerado processo de desintegração, os grupos étnicos sob seu domínio reivindicavam sua autonomia política e criavam seus próprios Estados, o que levou ao surgimento, no Cáucaso, das repúblicas da Armênia, do Azerbaijão - que reunia a população tártara - e da Geórgia. Os movimentos nacionalistas que motivaram a formação dos novos Estados impulsionaram também os conflitos étnicos, reavivando as rivalidades entre armênios e azerbaijanos e levando às primeiras disputas territoriais pelo Nagorno-Karabakh (PAPAZIAN, 2016, p. 28). Esse enfrentamento foi um dos elementos responsáveis pelo fracasso da Federação Transcaucasiana, aliança que as três repúblicas da região formaram logo após sua independência como forma de defender a sua autonomia frente às potências vizinhas (TER MINASSIAN, 2006).

Paralelamente aos enfrentamentos étnicos e nacionais que, durante a Grande Guerra, ocorriam nas áreas que haviam integrado o Império Russo, do outro lado da fronteira, no Império Otomano, os armênios eram vítimas de um massacre, um crime ainda sem nome e que apenas posteriormente teria sua definição: genocídio. O governo do Comitê União e Progresso, também conhecido como partido dos "Jovens Turcos", que assumira o poder em 1908, colocava em prática uma política de limpeza étnica que visava à aniquilação total da população armênia no Império (LOUREIRO, 2015). Não há dados precisos a respeito do número total de vítimas, mas estima-se que mais de um milhão de armênios foram executados entre 1915 e 19235. Esse processo levou a uma emigração massiva, que consolidou a diáspora armênia em diferentes partes do mundo e marcou indelevelmente a memória coletiva dessa população.

\footnotetext{
Eric Hobsbawm afirma que "A Primeira Guerra Mundial produziu a morte de um incontável número de armênios pela Turquia - a cifra mais aceita é de 1,5 milhão - o que pode ser considerada como a primeira tentativa moderna de eliminar toda uma população" (HOBSBAWM, 1996, p. 50). Donald Bloxham (2005) trabalha, por sua vez, com a estimativa de um milhão de armênios otomanos mortos, avalizado por pesquisas demográficas sobre o período da Grande Guerra.
} 


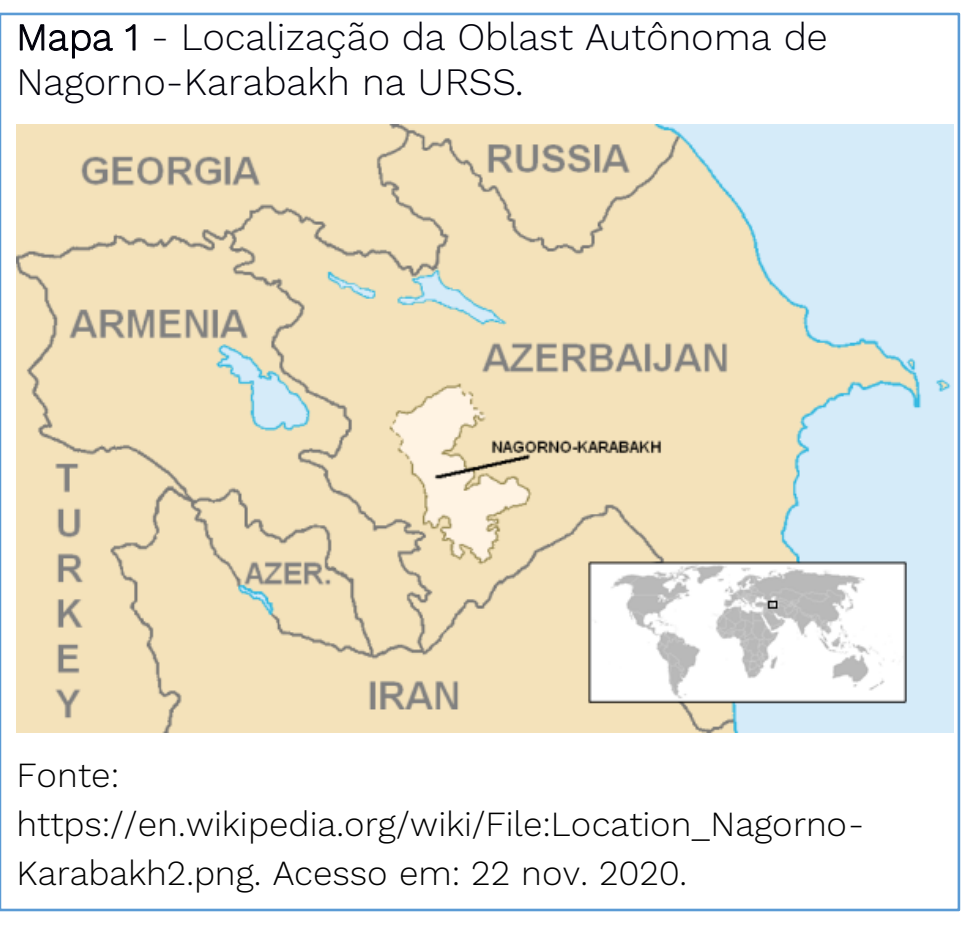

Quanto à disputa pela região do Nagorno-Karabakh, apenas em 1921 ela foi parcialmente pacificada (Mapa 1). Armênia e Azerbaijão haviam então sido anexados pela União Soviética e, portanto, o tema foi levado ao Kavburo, o comitê soviético para os assuntos do Cáucaso. A discussão da questão é descrita por Anahide Ter Minassian (1997, p. 83) no livro em que ela analisa a participação armênia na Federação Transcaucasiana. De acordo com a historiadora, o Kavburo decidiu, em sua sessão de 3 de julho de 1921, a favor dos armênios e determinou a vinculação do Nagorno-Karabakh à RSS da Armênia, baseando-se no entendimento de que a região era povoada majoritariamente por uma população armênia e não deveria, portanto, ser governada por outra nação. Todavia, no dia seguinte, o comitê reverteu a sua própria decisão e acolheu as demandas azerbaijanas, segundo as quais a região baixa de Karabakh estaria economicamente integrada ao Alto Karabakh - ou "Nagorno-Karabakh", em russo - e, assim, sua transferência às autoridades armênias poderia comprometer a sustentabilidade da planície azerbaijana. A decisão foi concretizada em 1923, quando o Kavburo atribuiu o caráter de "região autônoma ao Nagorno-Karabakh" e o submeteu às autoridades azerbaijanas em Baku (MOURADIAN, 1986, p. 57).

Moscou impunha, então, a chamada pax sovietica, que impedia a discussão de quaisquer temas de natureza étnica ou nacional, uma vez que tais questões eram vistas como uma ameaça à própria existência da URSS (D'ENCAUSSE, 1991). Assim, entre os anos 1920 e 1980 não houve enfrentamento direto entre armênios e azerbaijanos, embora a disputa por Nagorno-Karabakh continuasse a despertar animosidades em ambas as nações. Foi apenas no final da década de 1980, 
A guerra de Nagorno-Karabakh: as disputas em torno dos conceitos de 'vítima' e 'genocídio'

quando o poder central se enfraquecia e encontrava dificuldades para se impor sobre as diferentes regiões, que as tensões voltaram a aparecer.

Assim, em 1988, em conformidade com as reformas apresentadas por Mikhail Gorbachev, o soviete do Nagorno-Karabakh elaborou uma resolução na qual reivindicava a transferência da região para a RSS da Armênia. O documento foi aprovado em fevereiro daquele ano e imediatamente transmitido às autoridades soviéticas, mas não foi bem recebido em Moscou (LIBARIDIAN, 2004). As demandas da população do Nagorno-Karabakh foram consideradas como manifestações de desejos nacionalistas, que não corresponderiam ao projeto soviético e que poderiam alimentar pretensões separatistas no seio da União. A recepção foi ainda mais negativa em Baku, capital do Azerbaijão, onde a iniciativa foi vista como uma tentativa de espoliar o Azerbaijão de parte de seu território e taxada como uma traição orquestrada pelos armênios.

Acrescente-se que Abel Aganbekian - assessor econômico de Gorbachev - declarou aos armênios de Paris que desejaria ver a região de Nagorno-Karabakh unida à Armênia, o que fez com que Baku suspeitasse do apoio do politburo aos armênios (DE WAAL, 2010, p. 21). Isso levou à eclosão, em diversas cidades, de protestos contra a população armênia, os quais muitas vezes assumiram um caráter altamente violento. Nesse contexto, a cidade de Sumgait, polo petrolífero na periferia de Baku, tornou-se o palco de um grande massacre dos armênios que ali viviam. O episódio é assim descrito por Thomas de Waal (2010, p. 111), que o classifica como "a pior violência interétnica em quase 70 anos":

Na noite de 28 de fevereiro, uma multidão enfurecida marchou pelo centro da cidade [de Sumgait] e começou a atacar pessoas de etnia armênia em suas casas. Uma orgia de violência coletiva foi desencadeada: apartamentos foram incendiados e saqueados e armênios comuns foram atacados, estuprados e assassinados. Os pogroms se retroalimentaram, devido à lenta reação do oficialato soviético. Apenas vinte e quatro horas depois as tropas soviéticas seriam deslocadas e tomariam o centro da cidade, que se assemelhava então a uma zona de guerra. (DE WAAL, 2010, p. 111, tradução nossa) ${ }^{6}$

\footnotetext{
' Tradução livre de "On the evening of February 28, an angry crowd marched through the center of the town [of Sumgait] and began attacking ethnic Armenians in their homes. An orgy of mob violence was unleashed: apartments were burned and ransacked, and ordinary Armenians were attacked, raped, and murdered. The pogroms fueled themselves, as Soviet officialdom was slow to react. It was twenty-four hours before Soviet troops were deployed and retook the center of the town, which had come to resemble a war zone."
} 
Para os armênios em Nagorno-Karabakh, na Armênia Soviética e na diáspora, os massacres de 28 de fevereiro de 1988 em Sumgait despertaram a lembrança da noite de 24 de abril de 1915, quando militares otomanos foram às casas dos líderes da comunidade armênia de Constantinopla para prendê-los e, posteriormente, os deportar ou executar. A conexão simbólica entre os dois eventos foi sedimentada pela instalação de uma cruz de pedra dentro do complexo do Memorial ao Genocídio Armênio, em Yerevan, em homenagem às vítimas de Sumgait. A memória do genocídio armênio, tão importante para a construção de uma identidade armênia era, mais uma vez, invocada como uma espécie de alerta que armênios estavam novamente sob risco de serem eliminados de cidades e regiões que habitavam - 9\% da população de Sumgait era armênia (PAPAZIAN, 2001, p. 69). Ao mesmo tempo, ao invocar a memória do genocídio do começo do século XX, os armênios estabeleciam uma conexão entre o turco e o azerbaijano, criando uma espécie de um inimigo eterno que estaria sempre pronto a ameaçar a existência armênia. A aproximação simbólica dos povos turcos e azerbaijanos seria feita em diversos momentos ao longo da história conflituosa da região, seja por parte dos armênios, seja por parte de líderes nacionalistas turcos e azerbaijanos. Isso explica o aparecimento, após o colapso da URSS, da ideia de "uma nação, dois Estados", conforme fraseou Heydar Aliyev, presidente do Azerbaijão entre 1993 e 2003 (AZERBAIJÃO, 2010).

A partir daí, as posições se radicalizaram. Os armênios avançaram com o projeto de incorporação da oblast de Nagorno-Karabakh à Armênia Soviética, aprovando-o tanto no âmbito do Partido Comunista regional quanto no Soviete Supremo da Armênia. Ambas as medidas foram tornadas sem efeito por Moscou. Em 12 de julho de 1988, o Conselho Regional de Nagorno-Karabakh aprovou a secessão em relação ao Azerbaijão Soviético e a união à Armênia, mais uma vez rejeitada por Moscou, que, em janeiro de 1989, decidiu colocar a região sob seu controle direto (PAPAZIAN, 2001, p. 70). Nessa altura, as duas populações coabitavam a região cercadas em muita tensão, enquanto suas elites políticas assumiam posturas abertamente nacionalistas e antissoviéticas. 
O papel de Mikhail Gorbachev na condução da crise de Nagorno-Karabakh foi desastroso. Temendo a eclosão de outros processos semelhantes na URSS ${ }^{7}$, a posição de Moscou foi manter as fronteiras de suas repúblicas como estavam, enquanto trabalhavam para acalmar os ânimos populares e conter os secessionistas. De acordo com Angelo Segrillo:

O ano de 1990 também é marcado pela escalada e disseminação de conflitos étnicos em várias repúblicas, através do aparecimento de um fator complicador: diversas repúblicas autônomas e regiões autônomas, que sempre existiram no quadro das 15 repúblicas constitutivas da URSS, exigem também sua soberania em reação a estas. (SEGRILLO, 2000, p. 167, grifos do autor)

Ainda que houvesse tensão entre armênios e azerbaijanos e que a guerra de Nagorno-Karabakh tenha sido "o primeiro grande marco, que acordou o país [URSS] de seu 'sono dogmático' no campo étnico” (SEGRILLO, 2000, p. 166), a eclosão de um conflito interétnico fez parte de um contexto mais amplo de crise político-econômica da URSS (D’ENCAUSSE, 1991). Em um momento no qual as reformas de Gorbachev prometiam liberalização, as etnias no seio da União Soviética exigiam ajustes nas repúblicas constitutivas que pudessem dar vazão aos seus anseios nacionais ou econômicos.

Assim, para pastores azerbaijanos, por exemplo, a contiguidade territorial com Nagorno-Karabakh era economicamente estratégica, uma vez que eles ainda mantinham a prática de cruzar a área com seus rebanhos e famílias em determinadas épocas do ano em busca de novas pastagens. Nessa dinâmica, esses pastores criavam laços com a região e faziam daquelas montanhas e de seus recursos naturais uma parte de suas identidades e pertencimentos. Por isso, essa população era a mais resoluta em manter Nagorno-Karabakh como parte do Azerbaijão Soviético, em vez de anexá-lo à Armênia. Portanto, o ponto de Segrillo (2000, p. 172, grifo do autor) é relevante e merece ser levado em consideração como complemento às questões étnico-nacionais já abordadas: “A chave, a nosso ver, está no fato de que estes conflitos interétnicos serviram de conduit, de canal de transmissão (e amplificação), para contradições (insatisfações etc.) provindas de outras áreas, especialmente a econômica."

\footnotetext{
Na sequência da eclosão dos confrontos entre armênios e azerbaijanos, Geórgia, Uzbequistão, Cazaquistão e Quirguistão também foram palcos de disputas étnico-nacionais (D'ENCAUSSE, 1991; SEGRILLO, 2000, p. 167).
} 
O colapso da URSS e a saída das suas tropas do Cáucaso em 1991 marcam - início da guerra entre as recém-independentes repúblicas da Armênia e Azerbaijão e o momento mais violento dos conflitos. Nesse contexto, em 2 de setembro de 1991, poucos dias após a declaração de independência do Azerbaijão em relação à URSS, o soviete regional também declarou sua independência, instalando a República de Nagorno-Karabakh com capital em Stepanakert, numa tentativa de se estabelecer como parte no conflito (DE WAAL, 2003, p. 161).

Em 26 de fevereiro de 1992, no contexto das batalhas nas franjas de Stepanakert, os armênios tomaram a cidade de Khojaly a um alto custo de vidas de civis azerbaijanos que não foram evacuados antes da ofensiva das forças armênias. O evento ensejou alegações azerbaijanas de limpeza étnica - e, mais recentemente, de genocídio perpetrado pelos armênios - e justificativas armênias de uso da população civil como escudo humano por parte de militares do Azerbaijão. Muitos corpos foram levados para Aghdam, a maior cidade azerbaijana na cercania, onde foram velados na mesquita principal, a mesma que ainda permanece de pé, adicionando, assim, camadas simbólicas sobre esses eventos.

Se os armênios avançavam ao norte da capital, ao sul, Stepanakert ainda era ameaçada pelas posições azerbaijanas na cidade de Shushi, a 14 quilômetros de distância e 700 metros de altitude acima. Importante centro cultural para armênios e tártaros - que mais tarde iriam se identificar como azerbaijanos nos séculos XVIII e XIX, Shushi foi palco de uma disputa envolvendo tropas otomanas e armênias em 1918 e, posteriormente, um confronto entre nacionalistas azerbaijanos e a população armênia local, que causou a expulsão desses últimos. A cidade - que era, até os anos 1920, a terceira maior do Cáucaso, atrás de Tbilisi e Baku (CHORBAJIAN, 2001, p. 1) - teria então, durante o período soviético, 90\% de sua população composta por azerbaijanos (DE WAAL, 2003, p. 12) e uma posição estratégica em relação a Stepanakert.

A batalha por Shushi foi uma das mais importantes da guerra e seu fim, em 8 de maio de 1992, marcou a retomada do controle da cidade pelos armênios e a fuga da população azerbaijana para Baku. O mesmo ocorreu com as cidades 
A guerra de Nagorno-Karabakh: as disputas em torno dos conceitos de 'vítima' e 'genocídio' no tempo presente

Heitor Loureiro, Pedro Bogossian Porto

de Lachin' ${ }^{8}$ e Kelbajar', cuja ocupação pelas forças armênias possibilitou a contiguidade territorial entre a Armênia e o Nagorno-Karabakh e produziu, por outro lado, uma massa de milhares de deslocados internos azerbaijanos ${ }^{10}$. A população desalojada dessas regiões, em grande parte de origem curda, se instalou nas periferias das maiores cidades do Azerbaijão e passou a viver em contêineres e outras moradias improvisadas, constituindo uma crise social de grandes proporções. Desde então, a situação vem sendo explorada pelos governos da família Aliyev ${ }^{11}$ como símbolo da agressão e ocupação armênia do território azerbaijano.

Na esteira dos avanços armênios pelo controle de Nagorno-Karabakh, a Turquia fechou, unilateralmente, suas fronteiras com a Armênia em 1993, em solidariedade ao Azerbaijão e criando uma situação que perdura até o atual momento. No dia 3 de outubro daquele ano, Heydar Aliyev foi eleito presidente da República do Azerbaijão com 98,8\% dos votos (DE WAAL, 2003, p. 225). Natural de Nakhchivan ${ }^{12}$, enclave azerbaijano entre a Armênia, Turquia e Irã, descontínuo da maior parte do território do país, Heydar Aliyev fez carreira na burocracia soviética de segurança e inteligência, isto é, na KGB, onde graduou-se na academia Comitê de Segurança do Estado soviético em Leningrado (atualmente São Petersburgo), em 1949 (DE WAAL, 2003, p. 266). Militar e político experiente, Aliyev não conseguiu, contudo, conter os avanços armênios, que ocupariam, segundo Thomas De Waal:

[...] $4.088 \mathrm{~km}^{2}$ de Nagorno-Karabakh, cerca de 4,7 por cento do território do Azerbaijão. Os armênios ocupam integralmente cinco dos sete "territórios ocupados" fora de Nagorno-Karabakh. São eles: Kelbajar $\left(1.936 \mathrm{~km}^{2}\right)$, Lachin $\left(1.835 \mathrm{~km}^{2}\right)$, Kubatly $\left(802 \mathrm{~km}^{2}\right)$, Jebrail $\left(1.050 \mathrm{~km}^{2}\right)$ e Zengelan $\left(707 \mathrm{~km}^{2}\right)$. Eles também ocupam 77 por cento, ou $842 \mathrm{~km}^{2}$ dos $1.094 \mathrm{~km}^{2}$ da região de Aghdam (esse valor foi apresentado pelo chefe da região de Aghdam, Gara Sariev, na linha de frente em 19 de maio de 2001) e aproximadamente um terço (a julgar pelos mapas) ou $462 \mathrm{~km}^{2}$ dos $1.386 \mathrm{~km}^{2}$ da região de Fizuli. Os armênios ocupam também dois antigos vilarejos-

\footnotetext{
${ }^{8}$ Laçın, em azerbaijano, ftinănn (Berdzor) em armênio.

${ }^{9}$ Kalbacar em azerbaijano, fuuluufun (Qarvajar) em armênio.

10 Internally displaced persons (IDP), em inglês.

11 Heydar Aliyev foi presidente do Azerbaijão entre 1993 e 2003, sendo sucedido pelo seu filho, Itham, desde então. Ambos insistiram na retomada de Nagorno-Karabakh para realojar essa população.

12 Naxçıvan, em azerbaijano; Gupupquuu (Nakhichevan) em armênio.
} 
A guerra de Nagorno-Karabakh: as disputas em torno dos conceitos de 'vítima' e 'genocídio'

enclave de aproximadamente $75 \mathrm{~km}^{2}$ nas regiões de Nakhchivan e Kazakh. (Por sua vez, os azerbaijanos ocupam um antigo enclave armênio de cerca de $50 \mathrm{~km}^{2}$ ). Isso significa que, no total, a superfície do Azerbaijão sob controle armênio é de aproximadamente $11.797 \mathrm{~km}^{2}$, ou 4.555 milhas quadradas. A superfície total do Azerbaijão é de $86.600 \mathrm{~km}^{2}$. Portanto, a zona ocupada corresponde, na realidade, a 13,62 por cento do Azerbaijão [...]. (DE WALL, 2003, p. 286, tradução nossa) $)^{13}$

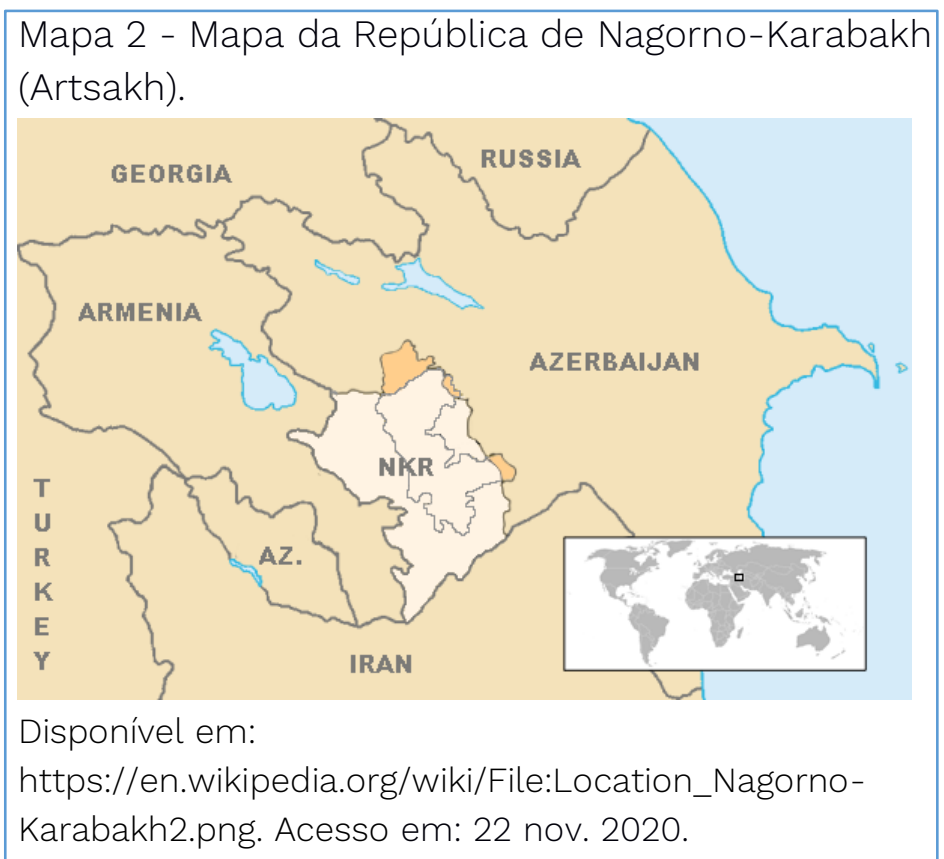

Internacionalmente, Nagorno-Karabakh era reconhecida como parte da República do Azerbaijão. Na prática, era uma república independente controlada por armênios que incluía, além da antiga oblast, sete regiões adjacentes, conforme apontado por De Waal no trecho acima (Mapa 2). A ocupação armênia foi discutida pelo Conselho de Segurança das Nações Unidas, que adotou quatro resoluções em 1993 - resoluções 822, 853, 874 e 884 - nas quais o Conselho critica a "ocupação armênia" e "reafirma a soberania e integridade territorial da República Azerbaijana e de todos os outros Estados na região" (ONU, 1993, p. 5, tradução nossa) $)^{14}$. Essas resoluções são recorrentemente lembradas por Baku como se fossem uma espécie de condenação internacional do controle armênio

\footnotetext{
${ }^{3}$ Traduzido livremente de "[...] 4,088 km² of Nagorny Karabakh, about 4.7 percent of the territory of Azerbaijan. The Armenians fully occupy five of the seven "occupied territories" outside Nagorny Karabakh. They are Kelbajar (1,936 km²), Lachin (1,835 km²), Kubatly (802 km2), Jebrail (1,050 km²), and Zengelan (707 km2). They also occupy 77 percent or $842 \mathrm{~km} 2$ of the 1,094 km2 of Aghdam region (this figure was given by the head of Aghdam region, Gara Sariev, at the front line on 19 May 2001) and approximately one-third (judging by maps) or $462 \mathrm{~km} 2$ of the 1,386 $\mathrm{km} 2$ of Fizuli region. The Armenians also occupy two former village enclaves of approximately $75 \mathrm{~km} 2$ in the Nakhichevan and Kazakh regions. (For their part, the Azerbaijanis occupy one former Armenian enclave of about $50 \mathrm{~km} 2$ ). This means that the combined area of Azerbaijan under Armenian control is approximately $11,797 \mathrm{~km} 2$ or 4,555 square miles. Azerbaijan's total area is $86,600 \mathrm{~km} 2$. So the occupied zone is in fact 13.62 percent of Azerbaijan [...]..

${ }^{14}$ Tradução livre de "reaffirming the sovereignty and territorial integrity of the Azerbaijani Republic and of all other States in the region".
} 
sobre Nagorno-Karabakh quando, em realidade, são chamados pela interrupção das hostilidades e envolvimento dos países da região no estabelecimento de uma paz duradoura, sem entrar no mérito do direito internacional sobre a região da antiga oblast de Nagorno-Karabakh.

A guerra foi congelada com os protocolos de Bishkek em maio de 1994, que estabeleceram um cessar-fogo entre Armênia, Azerbaijão e as forças de defesa da autoproclamada República de Nagorno-Karabakh. A resolução definitiva para a questão deveria ser negociada entre as partes por meio do chamado "Grupo de Minsk", da Organização para a Segurança e Cooperação na Europa, mediado por França, EUA e Rússia. Ao longo dos anos, o grupo foi criticado tanto por Yerevan quanto por Baku como sendo ineficaz na busca de uma resolução definitiva para a questão.

A situação permaneceria relativamente estável até abril de 2016, quando armênios e azerbaijanos voltaram a se enfrentar em um conflito aberto. Com uma duração de quatro dias, as novas hostilidades alteraram pouca coisa em relação ao status quo, mas mostraram ao mundo que o conflito estava longe de ser resolvido. Em 2017, a República de Nagorno-Karabakh realizou referendo constitucional que alterou o sistema político para o presidencialista e o nome do país para República de Artsakh, em referência ao antigo reino armênio que se estendia por uma região bem maior do que a oblast soviética. Em setembro de 2020, entretanto, teve início uma nova fase da guerra, para a qual o governo de Itham Aliyev recebeu o apoio bélico e logístico da Turquia de Recep Tayyip Erdoğan. Diferentemente do que ocorrera nos anos 1990 e em 2016, o conflito de 2020 foi marcado por substanciais vitórias militares azerbaijanas, o que reduziu pela metade a área controlada pelos armênios, sem, contudo, representar uma solução definitiva para o status da região (BAJALAN et al., 2020; GIGANTINO, 2020).

Nosso objetivo com essa breve análise da evolução histórica das hostilidades entre armênios e azerbaijanos não é meramente produzir uma genealogia do conflito atual, como se uma tal genealogia fosse suficiente para explicá-lo. Ao apresentar os principais episódios na escalada de tensões entre esses dois grupos, pretendemos apontar os elementos que dão sustentação às 
narrativas sobre esse conflito e, dessa maneira, torná-las mais inteligíveis. Destarte, se as memórias coletivas dependem de elementos concretos que thes deem sustentação, conforme defende Maurice Halbwachs (2006), são esses acontecimentos históricos que servem de referência às diferentes narrativas nacionais e que serão acionados para thes dar legitimidade. Com base nesses episódios, armênios e azerbaijanos concretizam aquilo que, para Michael Pollak (1992), seria a função essencial da memória: operar os elementos do passado a partir de um olhar eminentemente do presente.

\section{Martírio e redenção: a narrativa dos armênios sobre Nagorno-Karabakh}

Embora tenha sido interrompida por um cessar-fogo em maio de 1994, a guerra em Nagorno-Karabakh continua a ocupar um lugar central nas preocupações da população armênia. Isso se justifica, entre outras razões, pelo fato de que o conflito não foi efetivamente encerrado em 1994; portanto, a qualquer momento o enfrentamento direto poderia ser retomado. A esse elemento deve ser acrescentado o fato de que, mesmo em tempos de paz, as notícias que chegam da fronteira entre o Azerbaijão e a região de NagornoKarabakh são de que os disparos de atiradores de elite ocorrem quotidianamente, o que aumenta o clima de tensão na região.

A retomada das hostilidades entre armênios e azerbaijanos, ocorrida a partir de setembro de 2020, demonstra que os receios da população local não eram infundados. Essa foi, na realidade, a terceira vez em que o acordo de cessar-fogo foi oficialmente quebrado e que os dois países entraram em confronto direto - isso já havia ocorrido em abril de 2016, quando armênios e azerbaijanos se enfrentaram na chamada Guerra de Quatro Dias; e em julho de 2020, quando as Repúblicas do Azerbaijão e da Armênia - não Nagorno-Karabakh - entraram em disputa por postos de controle na fronteira entre as regiões de Tovuz e Tavush.

Para a população armênia, o risco que essa guerra representa é imenso, apesar de o país ter sido virtualmente vitorioso em 1994. À época, os armênios mantiveram o controle militar da antiga Oblast Autônoma de Nagorno-Karabakh, 
A guerra de Nagorno-Karabakh: as disputas em torno dos conceitos de 'vítima' e 'genocídio' no tempo presente

Heitor Loureiro, Pedro Bogossian Porto

como era chamada durante os tempos da URSS, e de sete distritos azerbaijanos adjacentes. Nesse território, os armênios proclamaram um Estado independente de fato, embora não seja reconhecido por nenhum Estado-membro das Nações Unidas. Desde então, cresceu vertiginosamente a disparidade econômica em relação ao Azerbaijão, que se tornou um dos maiores exportadores de hidrocarbonetos na região. É em razão do antagonismo entre Armênia e Azerbaijão que os gasodutos e oleodutos construídos na região contornam a Armênia para chegar até a Rússia, Turquia e Europa, principais importadores de Baku. Embora a ligação mais curta e menos onerosa entre Baku e Ankara seja através do território armênio, a escolha desse trajeto implicaria em garantir à Armênia recursos pelo uso de seu espaço terrestre e the daria o poder de interromper o abastecimento dos hidrocarbonetos vendidos à Turquia, o que não interessava ao Estado do Azerbaijão.

Impulsionado por tamanho desenvolvimento econômico, o governo azerbaijano aumentou em igual medida os investimentos em sua indústria militar e em seu material bélico - com apoio turco e israelense (IDDON, 2020) - de tal maneira que há hoje um nítido contraste com o potencial armamentista dos demais países da região caucasiana. Conforme observa Taline Papazian,

os números oficiais [do Tratado de Limitação] das Forças Convencionais na Europa acerca da Armênia e do Azerbaijão a partir de 2008 demonstram uma corrida armamentista na qual o Azerbaijão possui uma superioridade esmagadora, o que coloca o país em evidente violação de seu comprometimento em termos de limitação de veículos blindados de combate e de artilharia. (PAPAZIAN, 2016, p. 116, tradução nossa) ${ }^{15}$

Consciente da discrepância em relação ao poderio militar azerbaijano, a sociedade Armênia teme - e esse temor se manifesta nos discursos das lideranças políticas, dos meios de comunicação, bem como da população de maneira geral - que uma longa guerra termine com a vitória incontestável do país vizinho, que seria então capaz de retomar toda a região de Artsakh. Mais do que a mera perda de territórios, no entanto, os armênios temem que uma

\footnotetext{
15 Traduzido livremente de "les chiffres officiels du CFE pour l'Arménie et pour l'Azerbaïdjan depuis 2008 attestent d'une course aux armements dans laquelle l'Azerbaïdjan a une supériorité écrasante mettant ce pays largement en infraction avec ses engagements en termes de limitation des véhicules blindés de combat et d'artillerie".
} 
eventual vitória do Azerbaijão leve à expulsão ou mesmo ao extermínio de toda a população que vive atualmente na região, uma vez que não seria do interesse azerbaijano manter um enclave armênio em seu território. Nesse sentido, um desfecho favorável ao Azerbaijão poderia reproduzir os deslocamentos forçados realizados durante a primeira fase da guerra, entre 1988 e 1994, quando a população armênia no Azerbaijão e a população azerbaijana na Armênia foram obrigadas a deixar suas casas e migrar para a república vizinha, com a qual, no entanto, essas famílias raramente possuíam vínculos.

Os deslocamentos forçados e o risco de extermínio da população local despertam memórias ainda mais traumáticas entre os armênios, que associam essas medidas ao genocídio perpetrado no Império Otomano entre 1915 e 1923. Assim, de acordo com uma parcela expressiva da população armênia, uma eventual vitória azerbaijana na Guerra de Nagorno-Karabakh abriria caminho para mais um genocídio de armênios, como declarou uma de nossas entrevistadas:

Nós não temos o direito de perder - como nós dizemos - um centímetro de nosso país. O que território que nós reintegramos [em Nagorno-Karabakh]... Quanto ele vale? Muito sangue foi derramado: o sangue dos nossos irmãos, para quem a pátria, a Armênia, o país era um valor supremo. Então, se nós perdermos essa terra, a morte deles terá sido em vão e a população de Karabakh será massacrada. (PROFESSORA UNIVERSITÁRIA, 2016.)

Esse temor também não é um fato novo: em 1988, antes mesmo do início do confronto direto entre armênios e azerbaijanos, a população armênia já sinalizava o receio de um novo genocídio, uma vez que nem as autoridades azerbaijanas nem o comitê central soviético, em Moscou, pareciam dispostos a reprimir os massacres de armênios que aconteciam na cidade de Sumgait (DE WAAL, 2010, p. 111). Essa percepção foi amplamente documentada por Harutyun Marutyan (2009), em seu trabalho sobre a iconografia empregada pelo Movimento Karabakh, entre 1988 e 1990. Conforme o autor demonstra, cerca de um terço dos cartazes carregados pelos manifestantes estabeleciam algum tipo de conexão entre a situação dos armênios em Nagorno-Karabakh e aqueles que viviam no Império Otomano durante a Grande Guerra (MARUTYAN, 2009, p. 7-8). 
A guerra de Nagorno-Karabakh: as disputas em torno dos conceitos de 'vítima' e 'genocídio' no tempo presente

Heitor Loureiro, Pedro Bogossian Porto

O significado da luta por Nagorno-Karabakh começou a mudar para os armênios após o início do confronto direto e, sobretudo, após as primeiras vitórias militares importantes sobre as tropas azerbaijanas. Conforme já descrito aqui, uma das principais vitórias obtidas pelos armênios foi a cidade de Shushi' ${ }^{16}$, que era utilizada pelos azerbaijanos como uma posição estratégica no ataque à cidade de Stepanakert. Em virtude de sua importância no desenrolar do conflito, a batalha de Shushi frequentemente ocupa um lugar de destaque nas comemorações nacionais armênias, seja mencionada nos discursos oficiais, seja espontaneamente evocada pela população. Nas comemorações de independência da Armênia, por exemplo, é comum que, depois dos pronunciamentos das autoridades, crianças ocupem a Praça da República e façam no chão desenhos a giz. Nesses desenhos há invariavelmente, conforme pudemos observar em sucessivas incursões etnográficas, menções à Guerra de Nagorno-Karabakh e à batalha de Shushi [ver imagens 1, 2 e 3], o que demonstra a presença marcante desse episódio na memória coletiva da população.

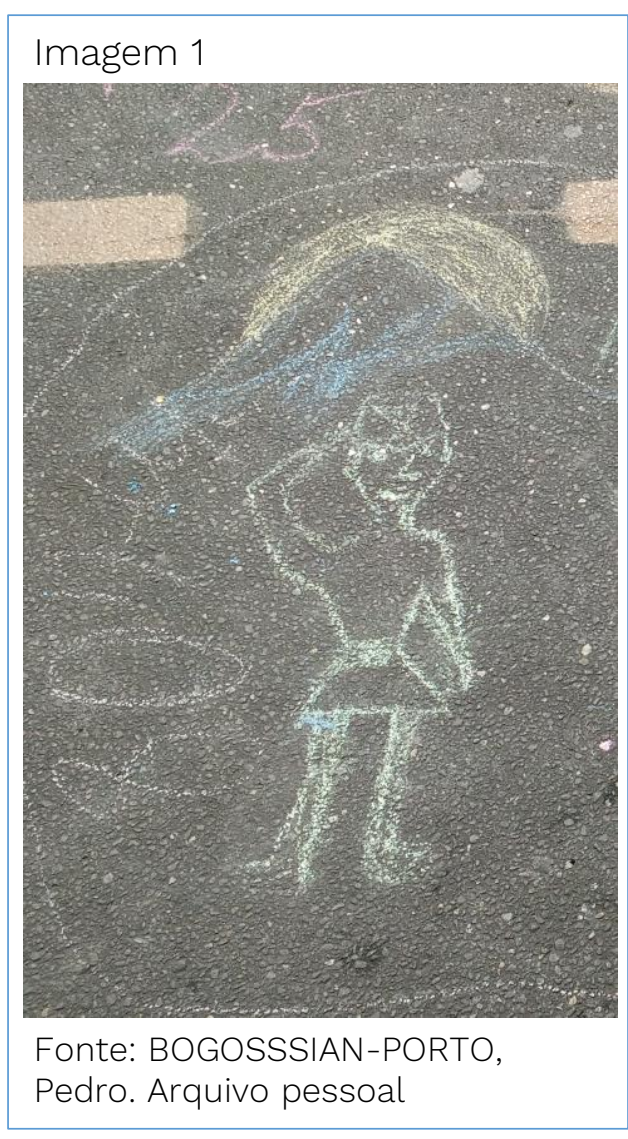

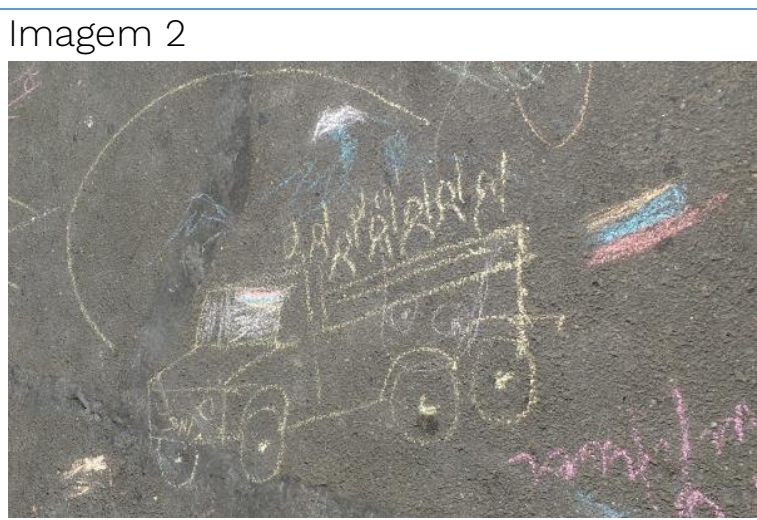

Fonte: BOGOSSSIAN-PORTO, Pedro. Arquivo pessoal

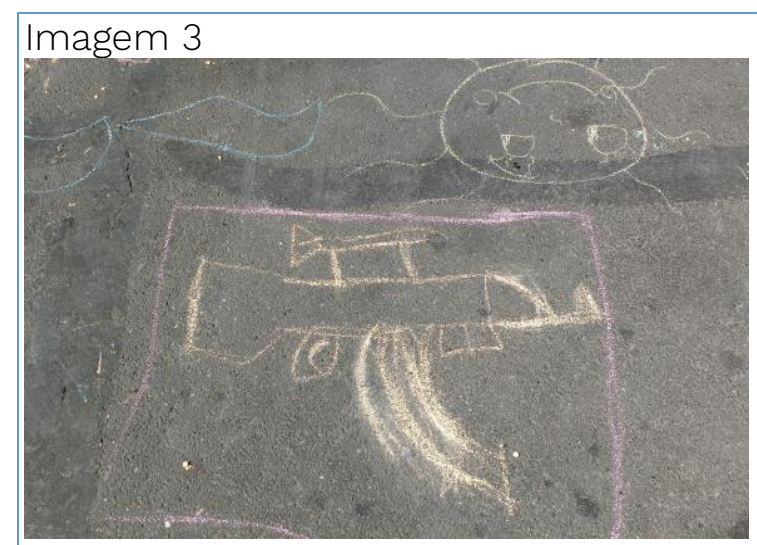

Fonte: BOGOSSSIAN-PORTO, Pedro. Arquivo pessoal

\footnotetext{
${ }^{16}$ Shusha (em azeri Şuşa ou em russo Шуша) ou Shushi (em armênio Gnı2h).
} 
Outro indicativo da força da vitória de Shushi no imaginário coletivo armênio é o fato de que o aniversário desta batalha, ocorrida em 8 de maio de 1992, é um feriado nacional armênio, celebrado junto com a vitória dos Aliados na II Guerra Mundial. Conforme nossas próprias observações de campo,

No dia 8 de maio ocorre uma grande festa no Parque da Vitória, em Yerevan. Muitas pessoas estão carregando bandeiras da Armênia e outras (inclusive civis e crianças) vestem-se com trajes militares. Ao centro do parque, em meio a tanques e canhões desativados, há um monumento em pedra erguido em homenagem à mãe armênia.

Hoje, em razão do aniversário da batalha de Shushi, um palco foi instalado diante do monumento e sobre ele uma banda formada por membros do exército toca canções nacionalistas e militares. [...] Os espectadores parecem especialmente emocionados por uma dessas canções, uma música melódica chamada "Brilha, Shushi", que eles cantam acompanhando os músicos. (BOGOSSIAN-PORTO, 2017, p. 3)

O fato de a guerra ter sido interrompida com uma vitória dos armênios é outro elemento central para as representações a seu respeito. É certo que se trata de uma vitória apenas parcial, porquanto as conquistas não são reconhecidas pelo Azerbaijão e tampouco pela comunidade internacional, mas ela é suficiente para alimentar entre os armênios a sensação de que teria havido um desfecho justo para a questão do Karabakh, sobre a qual os pleitos armênios vinham sendo sucessivamente ignorados. Assim, essa vitória teria o efeito de pacificar tanto o reconhecimento da soberania do Azerbaijão sobre o Nagorno Karabakh, em 1923, quanto a não aceitação da reivindicação da população da oblast, apresentada às autoridades soviéticas em 1988, para que a região fosse transferida para a administração armênia. Os avanços obtidos pelos armênios, que conquistaram não apenas a região de Nagorno-Karabakh, mas também as sete províncias adjacentes, representaria, portanto, a restituição da ordem, que teria sido quebrada quando o território passou a ser controlado pelas autoridades em Baku.

Além da percepção de uma "restituição da ordem" em relação ao Nagorno Karabakh, no entanto, a situação parcialmente consolidada em 1994 produziu um outro efeito simbólico de suma importância sobre a população armênia: ela ajudou a apaziguar a memória traumática do genocídio ocorrido entre 1915 e 1923. 
A guerra de Nagorno-Karabakh: as disputas em torno dos conceitos de 'vítima' e 'genocídio' no tempo presente

Heitor Loureiro, Pedro Bogossian Porto

Embora o adversário obviamente não fosse o mesmo, o caráter étnico da disputa entre azerbaijanos e armênios permitia a comparação com os massacres sucedidos cerca de setenta anos antes, conforme demonstrado por Pedro Bogossian-Porto (2017). É em razão dessa natureza étnica que os dois momentos históricos se tornam comparáveis e intercambiáveis, conforme observado também por Harutyun Marutyan (2009) e já mencionado neste texto.

Assim, se entre 1915 e 1923 os armênios foram um elemento passivo de sua própria história e se viram obrigados a se submeter aos desígnios de uma força externa - isto é, as autoridades otomanas - entre 1988 e 1994 eles foram capazes de assumir seu destino em suas próprias mãos e impor as suas posições a um grupo adversário. O relativo sucesso na Guerra do Karabakh foi percebido, portanto, como uma ruptura na lógica de dominação que, de acordo com determinada narrativa nacional, marcaria a história recente da população armênia. Isso produziu um impacto direto na imagem que os armênios produziam de si mesmos e representou uma libertação em relação modelo dominante até aquele momento, o que pode ser identificado em diversos relatos coletados entre a população. Conforme observa um de nossos entrevistados,

É claro que a Guerra de Nagorno-Karabakh trouxe muito sofrimento - foi um período muito duro e muitas famílias perderam seus filhos na guerra - mas a memória que nós temos desse período é muito mais da vitória que nós conquistamos ali. Nesse sentido, é uma memória bem diferente da que nós temos do genocídio, que é muito mais marcada pelos massacres sofridos pelos armênios. (PROFESSOR UNIVERSITÁRIO, 2020. Informação verbal.)

A associação que se faz entre a Guerra de Nagorno-Karabakh e o genocídio iniciado em 1915 traz ainda outro aspecto fundamental para se compreender a narrativa armênia a respeito do conflito. Uma vez que os armênios foram vítimas de um genocídio, considerado o crime máximo que pode ser impingido a uma população, todos os seus atos de guerra são considerados como uma reparação à violência sofrida, mais do que uma agressão a outros grupos. Isso se torna ainda mais relevante ao se considerar que o genocídio dos armênios até hoje não foi reconhecido pela comunidade internacional e que, consequentemente, não houve qualquer punição aos perpetradores ou indenização às vítimas (SMITH, 
A guerra de Nagorno-Karabakh: as disputas em torno dos conceitos de 'vítima' e 'genocídio'

2016). Dessa maneira, em se considerando as conquistas territoriais obtidas entre 1991 e 1994 como uma forma de justiça - e não de agressão - elas deveriam receber um status diferenciado, que não se confundiria com a narrativa mais ampla a respeito da guerra. Evidentemente, esse não é um discurso explicitado pelos atores sociais e políticos, mas ele frequentemente se encontra implícito nas declarações oficiais e nos discursos públicos. Um discurso proferido por Nikol Pashinyan, primeiro-ministro armênio, na abertura dos jogos pan$\operatorname{armênios}^{17}$ de 2019, ilustra de maneira bastante clara essa afirmação. Depois de afirmar em dois momentos diferentes que "Artsakh é Armênia", Nikol Pashinyan declara:

O terceiro consenso é que a soberania da Armênia e de Artsakh é o valor mais alto. Portanto, o povo armênio e o governo legítimo da Armênia devem e irão reagir fortemente a quaisquer forças que possam tentar se reportar a potências estrangeiras ao tratar de assuntos relacionados à Armênia e aos armênios. (THE PRIME MINISTER OF REPUBLIC OF ARMENIA, 2019, tradução nossa) ${ }^{18}$

Uma vez que Pashinyan, ao longo de seu discurso, vinha se referindo à população de Nagorno-Karabakh como "armênios", subentende-se que "assuntos relacionados à Armênia e aos armênios" se referia também às disputas pela região. Ele estaria, assim, justificando as ações armênias em NagornoKarabakh como legítima defesa.

O massacre ocorrido em Khojaly em 1992, considerado pelos azerbaijanos como um genocídio, é talvez o melhor exemplo do estatuto diferenciado que os armênios atribuem a seus próprios atos, os quais se justificariam por uma agressão sofrida anteriormente. As narrativas armênias sobre Khojaly alternam entre negar a responsabilidade pelos acontecimentos (INFORMATION, 2021) seja negando que eles tenham ocorrido, seja atribuindo-os às próprias autoridades azerbaijanas - e a afirmação de que o massacre fora merecido (APOSENTADO, 2017). Nesse caso, o argumento frequentemente apresentado é

\footnotetext{
${ }^{17}$ Os jogos pan-armênios são uma competição que a cada quatro anos reúne os armênios da diáspora. Normalmente eles ocorrem em Yerevan, capital da Armênia, mas em 2019 foram realizados pela primeira vez em Stepanakert, capital de Nagorno-Karabakh.

${ }^{18}$ Traduzido livremente de "The third consensus is that the sovereignty of Armenia and Artsakh is the highest value. Therefore, the Armenian people and the legitimate government of Armenia must and will strongly counteract against any such forces as may try to refer to foreign powers in dealing with matters related to Armenia and Armenians".
} 
de que a ação seria uma resposta ao pogrom antiarmênio realizado em Sumgait quatro anos antes, que supostamente legitimaria uma medida igualmente violenta. Desse modo, ao se representar sob o manto da categoria de vítima, os armênios obteriam uma espécie de salvo-conduto para ações que em outro contexto seriam consideradas inaceitáveis. Cumpre, portanto, analisar de maneira mais detida como essa memória foi e vem sendo instrumentalizada também entre os azerbaijanos.

\section{A narrativa do governo do Azerbaijão sobre a guerra de Nagorno- Karabakh: a vingança e o retorno à "Terra Prometida"}

No dia 9 de novembro de 2020, Armênia e Azerbaijão - com mediação russa, fora do contexto do Grupo de Minsk - anunciaram um cessar-fogo para a guerra que havia reiniciado seis semanas antes, no maior enfrentamento desde o cessar-fogo de 1994. Se nos anos 1990 o conflito foi congelado com o controle armênio do território de Nagorno-Karabakh e das sete regiões adjacentes, o acordo mais recente foi negociado com o Azerbaijão numa posição de vantagem. Além dos avanços militares das forças armadas azerbaijanas em Jebrail, Fizuli19 e Qubadlı - com apoio da Turquia e uso de drones adquiridos em Israel (IDDON, 2020) - que foram consolidados com a vigência do novo cessar-fogo, as autoridades das repúblicas da Armênia e Artsakh aceitaram desocupar as regiões de Lachin, Aghdam e Kelbajar, devolvendo o controle dessas a Baku, que celebrou o resultado como um "ponto final na resolução da questão"(AZERBAIJÃO, 2020). Entretanto, a questão de Nagorno-Karabakh está longe do fim.

O presidente do Azerbaijão Itham Aliyev proferiu, no dia 10 de novembro de 2020, o discurso de um vencedor. Presidente desde 2003, quando sucedeu seu pai, Heydar, Ilham Aliyev desejava uma vitória diplomático-militar sobre a Armênia há tempos. Como consequência da queda do preço dos hidrocarbonetos e da crise correlata ao novo coronavírus, a popularidade de Itham Aliyev sofreu um golpe em 12 de julho de 2020, quando forças armênias na região de Tavush - na fronteira entre Armênia e Azerbaijão, cerca de 200 km ao norte de Nagorno-Karabakh - ocuparam um posto de controle abandonado

\footnotetext{
${ }^{19}$ Cobrayıl e Füzuli, em azerbaijano.
} 
na zona desmilitarizada da fronteira. A vitória armênia levou a uma reação do exército azerbaijano, que foi, entretanto, rechaçada pelos armênios.

A escaramuça realimentou a rivalidade entre os dois povos, inflamando uma retórica belicosa em Baku. O porta-voz do ministro da Defesa azerbaijano Vagif Dargyakhly sugeriu bombardear a usina nuclear armênia de Metzamor, "o que seria uma grande tragédia para a Armênia" (RFE/RL, 2020), ao passo que o então ministro das Relações Exteriores armênio Zohrab Mnatsakanyan respondeu que o ato seria "genocida" (STRONSKI, 2020). Movida por tal clima de rivalidade, uma massa de 30 a 50 mil pessoas tomou as ruas da capital azerbaijana, na noite do dia 14 de julho, em protesto contra o que chamavam de "agressão armênia" e cantando "termine a quarentena, comece a guerra!" (OC MEDIA, 2020), "Karabakh é nossa" e "Karabakh ou morte" (EURASIANET, 2020). Um grupo ocupou, então, o edifício do parlamento azerbaijano, com o intuito de pressionar o governo por uma ação mais enérgica em Nagorno-Karabakh. Quando a iniciativa foi dispersada pela polícia, os manifestantes criticaram aos gritos a truculência policial, dizendo que "eles são piores que os armênios" (EURASIANET, 2020).

Apesar dos 16 militares mortos e dos bombardeios de instalações civis em Tavush, na Armênia, e Tovuz, no Azerbaijão, o conflito de julho de 2020 não ganhou escala, mas mostrou a Ilham Aliyev que havia apoio popular para uma ofensiva em Nagorno-Karabakh. No fim daquele mês, a Turquia e o Azerbaijão promoveram grandes exercícios militares no Cáucaso (CAUCASUS WATCH, 2020), tanto no Azerbaijão, quanto em Nakhchivan. Em seguida, a Turquia cederia a seu aliado caças F16 e uma grande quantidade de drones Bayraktar, que seriam largamente utilizados na retomada da guerra de Nagorno-Karabakh.

Aproveitando-se do apoio político doméstico, do suporte bélico-logístico turco, da atenção estadunidense voltada para as suas eleições presidenciais, da crise em Belarus ocupando Putin, do aumento dos casos de contaminação pelo novo Coronavírus na Europa e da inferioridade militar armênia, Itham Aliyev lançou uma ofensiva militar contra Nagorno-Karabakh em 27 de setembro de 2020. Apesar do relevo da região garantir uma posição favorável às forças de defesa armênias da autoproclamada República de Artsakh, as forças azerbaijanas 
A guerra de Nagorno-Karabakh: as disputas em torno dos conceitos de 'vítima' e 'genocídio' no tempo presente

Heitor Loureiro, Pedro Bogossian Porto

conseguiram, ao longo de 44 dias de confronto, avançar pelo Sul da República de Artsakh - entre a antiga oblast de Nagorno-Karabakh e a fronteira com o Irã - até a fronteira com a República da Armênia. Para tanto, elas contaram com o reforço dos mercenários do Exército Livre Sírio, apoiados pela Turquia (SYNOVITZ, 2020). A partir do sul da República de Artsakh, as tropas azerbaijanas conseguiram rumar em direção ao norte, em busca de tomar o corredor de Lachin e a cidade histórica de Shushi, o que ocorreu em 8 de novembro. Com mais de cinco mil mortos e cerca de metade da população armênia tendo que deixar Nagorno-Karabakh20, os armênios se viram forçados a negociar e a aceitar o novo status quo.

Mapa 3 - Mapa do controle de Nagorno-Karabakh a partir do cessar-fogo de novembro de 2020.

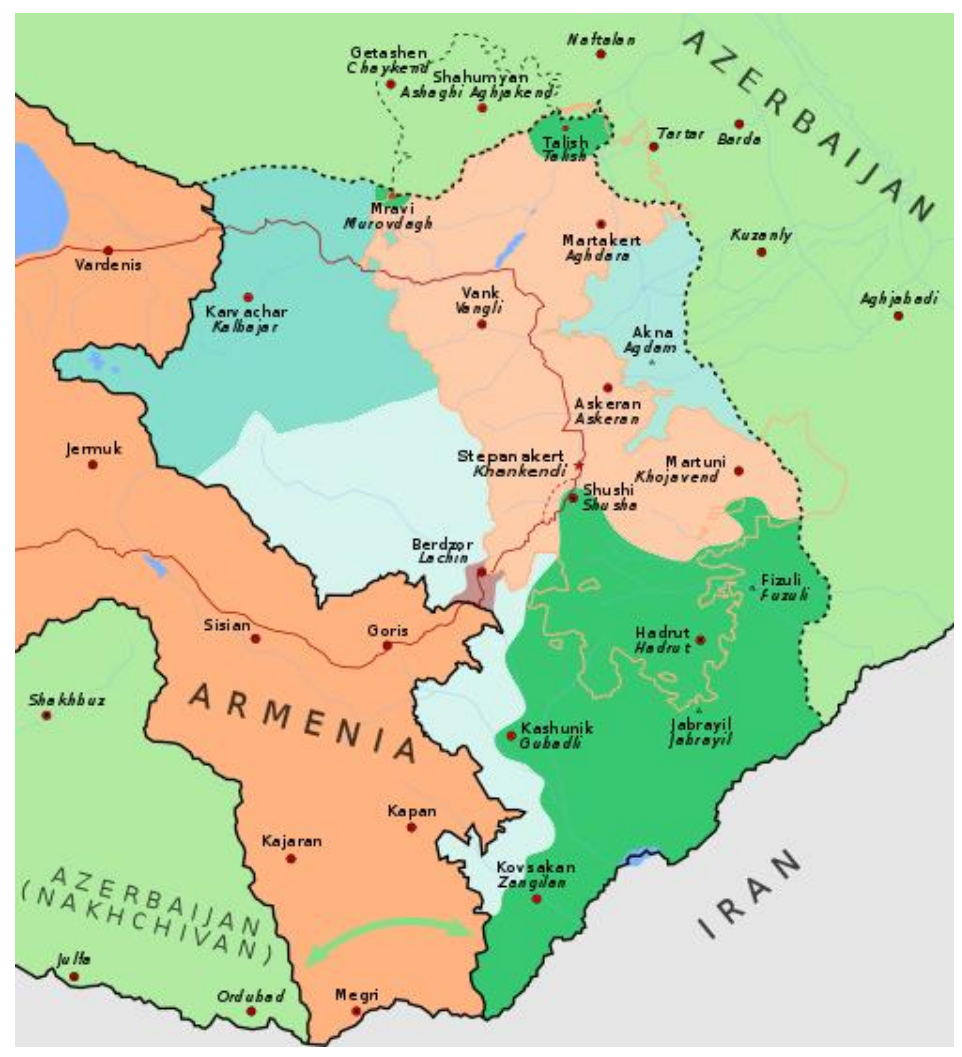

Disponível em:

https://en.wikipedia.org/wiki/File:2020_Artsakh_ceasefire_ map.svg. Acesso em: 22 nov. 2020.
O dia 10 de novembro de 2020 - quando foi feita a declaração trilateral armênia, azerbaijana e russa, pondo fim à atual fase da guerra foi celebrado por Itham Aliyev como "um dia histórico para o nosso país". No pronunciamento à nação, o presidente azerbaijano divulgou: o cessar-fogo com a manutenção das posições de momento; o retorno de Aghdam, Kelbajar e Lachin ao controle de Baku; a presença de 1.960 soldados russos como peacekeepers na linha de contato de NagornoKarabakh/Azerbaijão e no corredor de Lachin; a retirada de tropas armênias dessas mesmas regiões; o

\footnotetext{
${ }^{20}$ Os números ainda estão em disputa. Baku não revelou quantos de seus militares morreram. As estimativas dão conta que o número de mortos na atual fase do conflito pode ser o dobro do inicialmente divulgado (TROIANOVSKI, 2020).
} 
retorno de deslocados internos sob supervisão do Alto Comissariado das Nações Unidas para Refugiados; a troca de prisioneiros e corpos de militares mortos; e, por fim, a garantia por parte da República da Armênia de um corredor ligando o Azerbaijão à Nakhchivan (AZERBAIJÃO, 2020) (Mapa 3).

A declaração - que não é um acordo de paz - foi chamada por Aliyev de uma "vitória gloriosa". Segundo o presidente do Azerbaijão, o primeiro-ministro armênio Nikol Pashinyan foi:

forçado por nós a fazê-lo [assinar o documento]. [...] ele não está assinando de boa vontade. Ele está assinando sob a pressão do nosso punho de ferro [...] Pashinyan foi forçado a assinar essa declaração - de uma forma muito patética e miserável. Eu assineia com muito orgulho e alegria, pois essa declaração termina com a longa ocupação [...]. (AZERBAIJÃO, 2020)

Portanto, o documento seria ainda, segundo ele, produto de "nossa brilhante vitória, de nossa histórica vitória, da libertação de Shusha da ocupação". Sobre a cidade histórica, Aliyev afirma que:

Shusha é a coroa de Karabakh! A libertação de Shusha tem grande significado político e estratégico, além de moral. Nós retornamos a Shusha, nós retornamos a Shusha, nós viveremos em Shusha, pessoas viverão em todas as outras terras liberadas da ocupação. Pessoas retornarão a essas terras, viverão lá, a espera de 30 anos do nosso povo terminará. (AZERBAIJÃO, 2020)

A ênfase de Aliyev na retomada de Shushi/a não é casual. Como vimos, a cidade é central na construção da identidade e pertencimento de armênios e azerbaijanos na região e foi palco de massacres e batalhas ao longo do século XX. Na guerra de Karabakh nos anos 1990, a entrada das forças armênias em Shushi e a evacuação dos azerbaijanos foi um duro golpe no governo do presidente interino Yagub Mamedov, que havia assumido após a renúncia de Ayaz Mutalibov na sequência da tomada de Khojaly (DE WAAL, 2003, p. 173). Ainda que Mutalibov tivesse conseguido recuperar o poder momentaneamente, Heydar Aliyev, com o apoio do parlamento azerbaijano, ascenderia à presidência em 1993. Aproveitando-se do caos político em Baku, os armênios avançaram sobre Zengelan, Fizuli e Jebrail, forçando Aliyev-pai a negociar, sem conseguir recuperar os territórios perdidos pelos seus antecessores (DE WAAL, 2003, p. 226). De certa 
A guerra de Nagorno-Karabakh: as disputas em torno dos conceitos de 'vítima' e 'genocídio'

maneira, a vitória de Aliyev-filho na batalha de Shushi/a de 2020 é a consecução de algo não alcançado pelo pai, cujo túmulo foi visitado por Itham e pela primeiradama, Mehriban Aliyeva - que também é a vice-presidente do país - horas antes do pronunciamento (AYDOGAN et. al., 2020).

Desde o cessar-fogo de 1994, Baku alega que um milhão de deslocados internos tiveram que deixar Nagorno-Karabakh - cifra que autores como Thomas De Waal (2003, p. 285) consideram superestimada - e viver nas periferias das grandes cidades do Azerbaijão em moradias improvisadas. A impossibilidade de retorno dessas centenas de milhares de pessoas às suas vilas e cidades em Nagorno-Karabakh foi, recorrentemente, objeto dos pronunciamentos de Iham Aliyev, que lembrava que a ocupação armênia forçava essas pessoas a morarem em situação precária - obliterando o fato de que cerca de 350 mil armênios também precisaram deixar o Azerbaijão e migrar para a Armênia, Rússia ou alhures (DE WAAL, 2003, p. 285). Em suma, os deslocados internos oriundos da Guerra de Nagorno-Karabakh entre os anos 1980-90 são uma importante força política e base de apoio para o governo Aliyev, que os mantêm mobilizados a partir da promessa do retorno à uma espécie de "terra prometida" em Karabakh. No discurso subsequente à declaração de 10 de novembro, Aliyev ressalta:

[...] o principal desejo deles [deslocados internos] tem sido o retorno às suas terras e eles me pediam "Sr. Presidente, por favor nos mande de volta para lá"; Todas as vezes que eu me encontrava com eles, eu via uma forte determinação, invencibilidade e lealdade ao Estado, mas ao mesmo tempo eu via luto e saudade nos olhos deles. Isso terminou, meus caros compatriotas, que seus olhos vejam com clareza agora, vocês estão voltando, nós estamos voltando, o Azerbaijão está voltando! O Azerbaijão está restaurando sua integridade territorial. Poderia haver maior felicidade? (AZERBAIJÃO, 2020)

Ainda sobre a possibilidade de retorno dos deslocados às suas terras, o mandatário azerbaijano continua, na mesma nota regozijante:

"Em nossas mesquitas semidestruídas nas terras libertadas, o inimigo bárbaro criava porcos para nos insultar e ferir nosso orgulho. Mas nós tivemos a nossa revanche com uma vingança. Nós vingamos as vítimas de Khojaly, nós vingamos nossos mártires [...] ele [Pashinyan], que manteve porcos em nossas mesquitas, é quem é um porco" (AZERBAIJÃO, 2020). 
Nos últimos anos, surgiram em redes sociais fotos que seriam do interior de mesquitas azerbaijanas em territórios controlados por armênios servindo como abrigo para animais, incluindo porcos - cuja criação e consumo são vetados no Islã - o que gerou a revolta de usuários azerbaijanos (PIGS, 2019) . O fato de as fotos terem sido tiradas, supostamente, no interior da mesquita de Aghdam deu mais uma volta no parafuso da revolta azerbaijana com o controle armênio da cidade, que até 1993 tinha 50 mil habitantes. Além de ser uma grande cidade azerbaijana, Aghdam serviu como refúgio para aqueles que conseguiram deixar Khojaly quando do cerco armênio e dos que não conseguiram, cujos corpos foram enterrados no cemitério de Aghdam.

O episódio de Khojaly ocorreu em fevereiro de 1992, quando forças armênias cercaram a cidade - onde está o único aeroporto de Nagorno-Karabakh - e determinaram a evacuação dos civis da região. Cerca de 485 azerbaijanos, de acordo com as estimativas oficiais de Baku (DE WAAL, 2003, p. 171), teriam morrido nesse deslocamento, em circunstâncias que até hoje não são claras (LIBARIDIAN, 2019). O Azerbaijão passou a tratar o massacre como um crime de "genocídio" - tal qual tipificado na Convenção para a Prevenção e Punição ao Crime de Genocídio, aprovada pela Assembleia Geral das Nações Unidas em 9 de dezembro de 1948 - e tem reivindicado seu reconhecimento pela comunidade internacional. Com isso, Baku pretende angariar apoio para uma causa e dar visibilidade para certa realidade, configurando o que o historiador e politólogo francês Jacques Sémelin (2009) definiu como "usos políticos dos massacres e genocídios".

O massacre de Khojaly foi tomado por Baku como o símbolo maior da Guerra de Nagorno-Karabakh e do controle armênio da região sendo, não raramente, referido como um genocídio pelas autoridades azerbaijanas, que se esforçam para que governos regionais e nacionais o reconheçam como tal. É notório o esforço feito pelo governo do Azerbaijão nos anos 2010 para aprovar, em parlamentos nacionais, resoluções nessa direção. O primeiro desses países foi o México em 2011, seguido no continente americano pela Colômbia. Paquistão, antigo aliado de Baku, também o fez - o governo de Islamabad é o único do 
mundo que não reconhece a República da Armênia, em solidariedade ao Azerbaijão (KORYBKO, 2020).

A partir do intenso lobby azerbaijano no México e, posteriormente, em outros países da América Latina, acadêmicos desconfiaram do surgimento de moções de reconhecimento do genocídio de Khojaly em países com pouca ou nenhuma organização coletiva de armênios. Após reportagens investigativas de jornalistas latino-americanos, ficou claro um modus operandi: autoridades diplomáticas azerbaijanas se aproximavam de parlamentares latino-americanos, patrocinavam viagens ao Azerbaijão, os municiavam de insumos sobre os eventos em Khojaly produzidos por órgãos oficiais e, eventualmente, propunham a aprovação de resoluções reconhecendo o alegado genocídio (ANTARAMIÁN, 2013). Às vésperas do centenário do genocídio armênio, em 2015, e com a crescente mobilização de armênios por todo o mundo para pressionar a República da Turquia a reconhecer os crimes cometidos pelo Império Otomano, Baku passou a trabalhar como linha auxiliar da diplomacia turca invertendo a acusação: não só o genocídio armênio era uma farsa, como, na realidade, os armênios é que teriam cometido genocídio contra a população azerbaijana. Isso revela a importância da noção de "vítima" e da disputa pela categoria de "genocídio" nos discursos das duas populações.

\section{Conclusão}

Na madrugada do dia 23 para o 24 de abril de 2015, dezenas de milhares de pessoas se aglomeravam na Praça da República de Yerevan, capital da República da Armênia, para (co)memorar o centenário do genocídio armênio perpetrado pelo Império Otomano durante a Grande Guerra. No palco montado na praça, se apresentava a banda de rock estadunidense system of a Down, composta por quatro membros descendentes de sobreviventes do genocídio. Em um determinado momento do show, o guitarrista Daron Malakian gritou ao microfone: "isso não é só um show de rock and roll. Para os nossos assassinos, isso é vingança!", para delírio do público, formado, em sua maioria, também por descendentes de sobreviventes (BOGOSSIAN-PORTO, 2018). Para eles e outros 
A guerra de Nagorno-Karabakh: as disputas em torno dos conceitos de 'vítima' e 'genocídio' no tempo presente

Heitor Loureiro, Pedro Bogossian Porto

milhões de armênios que compõem uma numerosa diáspora, o genocídio iniciado em 1915 não é algo do passado, mas um tema do tempo presente.

Para alguns, na medida em que o genocídio é negado ele ainda ocorre, em um continuum que liga os mortos na noite de 24 de abril de 1915 em Constantinopla aos soldados armênios mortos nos mais recentes enfrentamentos em Nagorno-Karabakh. Nessa narrativa, os armênios morreriam por serem armênios, enquanto o perpetrador turco-azerbaijano (categorias que se tornam intercambiáveis, uma vez que ocupam a mesma posição de "agressor") deseja eliminá-los pela mesma razão essencialista. Assim como os 1,5 milhão de vítimas do genocídio armênio eram considerados mártires - até que a Igreja Apostólica Armênia os canonizou em 2015 (ARMENIAN, 2020) - aqueles militares mortos em combate contra as forças azerbaijanas também o são, como afirmou o primeiro-ministro, Nikol Pashinyan, em 12 de novembro de 2020: "Os parentes de nossos mártires podem estar se perguntando por que, afinal, seus entes queridos morreram. A resposta a esta pergunta é, em primeiro lugar: para salvar o povo de Artsakh do genocídio, para proteger o direito do nosso povo à sobrevivência” (THE PRIME MINISTER OF REPUBLIC OF ARMENIA (2020). Em suma, para os armênios, a guerra de Nagorno-Karabakh não é uma guerra por território, mas pela existência do povo armênio.

Para a narrativa oficial azerbaijana, se houve um genocídio, foi o cometido em Khojaly em 1992, do qual os armênios são perpetradores, não vítimas. Esse evento, a fuga dos sobreviventes - e o traslado dos corpos - para a vizinha Aghdam e a subsequente destruição e ocupação desta cidade pelas forças armênias são fundamentais para a construção da narrativa azerbaijana enquanto vítima de uma agressão armênia. Os mortos e, sobretudo, as centenas de milhares de deslocados internos azerbaijanos que, por causa da ocupação armênia, não podiam retornar às terras que haviam povoado são o cerne da retórica de Baku sobre justiça e direito em Nagorno-Karabakh. Em seu discurso de "vitória" em 10 de novembro de 2020, Itham Aliyev menciona a palavra "terra" 31 vezes, ufanando-se do fato de que os armênios não mais controlam a maior parte da região. Ademais, a pequena porção de terra ainda controlada por armênios não terá status especial, como autonomia ou independência. Segundo 
Aliyev: "O status foi para o inferno, falhou, foi despedaçado, não existe e não existirá. Enquanto eu for presidente, não haverá status" (AZERBAIJÃO, 2020).

Em vídeo que viralizou nas redes sociais durante os conflitos de 2020, um soldado armênio entoava a canção patriótica Gini Lits ${ }^{21}$ enquanto caminhava com dois colegas (ARMENIAN, 2020). A música versa sobre a execução de Mehmet Talat Paxá, Ministro do Interior do Império Otomano e principal arquiteto do genocídio armênio, morto a tiros nas ruas de Berlim em 1921 por Soghomon Tehlirian, membro da Federação Revolucionária Armênia (BOGOSIAN, 2015). Na primeira estrofe, cantam os armênios: "O mundo tremeu ante a força dos armênios. O trono turco foi ao chão. Deixe-me te contar a história da morte de Talat”. Quase um século depois do evento, armênios ainda cantavam a morte de Talat Paxá, enquanto marchavam em direção ao front de batalha em suas fardas camufladas marcadas com uma grande cruz branca no peito. Do outro lado da linha de contato, soldados azerbaijanos se preparavam para a ofensiva que expulsaria os "invasores" de suas terras ancestrais e permitiria a união territorial com seus compatriotas azerbaijanos em Nakhchivan e, eventualmente, até mesmo com os seus "irmãos" turcos. Em célebre frase, Hobsbawm (1998, p. 243) nos lembra que "toda história é história contemporânea disfarçada". Na história compartilhada por armênios, azerbaijanos e turcos, o uso da história como instrumento de justificativa e motivação para ações políticas e militares faz com que esse disfarce seja dispensável.

${ }^{21}$ q.hụ L.hg, em armênio. 
A guerra de Nagorno-Karabakh: as disputas em torno dos conceitos de 'vítima' e 'genocídio'

\section{Referências}

ANTARAMIÁN, Carlos. Abusing the term "Genocide" in distant domains: the statue of Aliyev and the Khojaly Massacre in two squares in Mexico City. Journal of the Society for Armenian Studies, Fresno, v. 22, p. 263-77, 2013.

APOSENTADO armênio. [Entrevista concedida a] Heitor Loureiro, Ivanyan (Nagorno-Karabakh), 3 maio 2015. (Arquivo pessoal).

ARMENIAN church makes saints of 1915 genocide victims. Deutsche Welle, Bonn, 23 Apr. 2015. Available in: https://www.dw.com/en/armenian-church-makessaints-of-1915-genocide-victims/a-18405330. Access on: 22 Nov 2020.

ARMENIAN troops singing the famous Armenian war song "Gini Lits". NagornoKarabakh, 06 out. 2020. 1 vídeo (57 seg). Disponível em: https://youtu.be/Z8Bfry8CnLs. Acesso em: 21 abr. 2021.

AYDOGAN, Merve; ALIYEV, Jeyhun; BIR, Burak. Anadolu Agency, Ancara, 08 Nov. 2020. Available in: https://www.aa.com.tr/en/azerbaijan-front-line/shusha-cityfreed-from-armenias-occupation-azerbaijan/2036192. Access on: 22 Nov. 2020.

AZERBAIJÃO. Joint press statements of Presidents of Azerbaijan and Turkey. Baku, 15 Sep 2010. Available in: https://en.president.az/articles/736/print. Access on: 21 Apr 2021.

AZERBAIJÃO. Ilham Aliyev addressed the nation. Baku, 10 Nov. 2020. Available in: https://en.president.az/articles/45924. Access on: 22 Nov. 2020.

BAJALAN, Djene, YILDIZ, Sara Nur; DAVIDIAN, Vazken Khatchig. O que de fato move o conflito entre Azerbaijão e Armênia. Jacobin Brasil, São Paulo, 17 out. 2020. Disponível em https://jacobin.com.br/2020/10/o-que-de-fato-move-oconflito-entre-azerbaijao-e-armenia/. Acesso em: 17 nov. 2020.

BLOXHAM, Donald. The great game of genocide: imperialism, nationalism, and the destruction of the Ottoman Armenians. Nova York: Oxford University Press, 2005.

BOGOSIAN, Eric. Operation Nemesis: the assassination plot that avenged the Armenian Genocide. Nova York: Little Brown, 2015.

BOGOSSIAN-PORTO, Pedro. 'É o renascimento de uma identidade nacional!': a relevância da guerra e do genocídio no nacionalismo armênio. Hades: Revista Interdisciplinar, Osasco, n. 1, p. 168-189, 2017. 
A guerra de Nagorno-Karabakh: as disputas em torno dos conceitos de 'vítima' e 'genocídio' no tempo presente

Heitor Loureiro, Pedro Bogossian Porto

BOGOSSIAN-PORTO, Pedro. Forget me not: the drama of building an identity on the centennial of genocide of the Armenians. Genocide Studies International 12, Toronto, n. 2, p. 191-207, 2018.

BOGOSSSIAN-PORTO, Pedro. Notas de campo. Yerevan: [s.n.], 2016.

CAUCASUS WATCH. Military exercises in the Caucasus: a war of nerves between Baku and Yerevan. [S.l.], 4 Aug. 2020. Available in:

https://caucasuswatch.de/news/2935.html. Access on: 22 Nov. 2020.

CHORBAJIAN, Levon. Introduction. In: CHORBAJIAN, Levon. (org). The making of Nagorno-Karabagh: from secession to republic. New York: Palgrave Publishers, 2001. p. XI-XIII.

CONSTITUTION OF THE UNION OF SOVIET SOCIALIST REPUBLICS. Adopted at the extraordinary eighth congress of soviets of the U.S.S.R. [S.L.], 5 Dic. 1936. Available in: https://constitutii.files.wordpress.com/2013/01/1936-en.pdf. Access on: 19 Mar. 2021.

D’ENCAUSSE, Hélène Carrère. La décomposition de l’Empire soviétique.

Pouvoirs: revue française d'études constitutionnelles et politiques,

Nationalismes, Paris, n. 57, p. 19-31, 1991.

DE WAAL Thomas. Black garden: Armenia and Azerbaijan through peace and war. New York: New York University Press, 2003.

DE WAAL Thomas. The Caucasus: an introduction. Oxford: Oxford University Press, 2010.

EURASIANET. Pro-war Azerbaijani protesters break into parliament. Eurasianet, Nova York: 15 July 2020. Available in: https://eurasianet.org/pro-war-azerbaijaniprotesters-break-into-parliament. Access on: 22 Nov. 2020.

EURASIANET. The Caucasus: an introduction. Oxford: Oxford University Press, 2010.

FICO, Carlos. História do tempo presente, eventos traumáticos e documentos sensíveis: o caso brasileiro. Varia Historia 28, Belo Horizonte, n. 47, p. 43-59un. 2012.

GIGANTINO, Bryan. A luta entre Armênia e Azerbaijão: um conflito com raízes profundas. In: JACOBIN BRASIL, 25 out. 2020. Disponível em:

https://jacobin.com.br/2020/10/a-luta-entre-armenia-e-azerbaijao-um-conflitocom-raizes-profundas/. Acesso em: 17 nov. 2020. 
A guerra de Nagorno-Karabakh: as disputas em torno dos conceitos de 'vítima' e 'genocídio' no tempo presente

Heitor Loureiro, Pedro Bogossian Porto

HALBWACHS, Maurice. A memória coletiva. São Paulo: Centauro, 2006.

HOBSBAWM, Eric. The age of extremes. Nova York: First Vintage Books, 1996.

HOBSBAWM, Eric. O presente como História. In: SOBRE HISTÓRIA. São Paulo: Companhia das Letras, 1998. p. 243-255.

KORYBKO, Andrew. Why is Pakistan the only country that does not recognise Armenia? The Express Tribune, Karachi, 21 July 2020. Available in: https://tribune.com.pk/article/97102/why-is-pakistan-the-only-country-thatdoes-not-recognise-armenia. Access on: 22 Nov. 2020.

IDDON, Paul. Azerbaijan's growing drone arsenal may have led it to believe it has edge over Armenia. Forbes, Jersey City, 7 Oct. 2020. Available in:

https://www.forbes.com/sites/pauliddon/2020/10/07/how-effective-isazerbaijans-growing-drone-arsenal/?sh=5b67354e114c. Access on: 22 Nov. 2020.

LOUREIRO, Heitor. Genocídio armênio: uma introdução histórica. Política

Externa, São Paulo, v. 23, n.1-2, 015.

LIBARIDIAN, Gerard J. Modern Armenia: people, nation, state. New Brunswick: Transaction Publishers, 2004.

LIBARIDIAN, Gerard J. An Armenian perspective on Khojali. OpenDemocracy, [s.l.], 28 Feb. 2014. Available in: http://www.opendemocracy.net/gerardlibaridian/armenian-perspective-on-khojali. Access on: 22 Nov. 2020.

MARUTYAN, Harutyun. Iconography of Armenian identity: the memory of genocide and the Karabagh Movement. Yerevan: Gitutyun Publication House, 2009.

MOURADIAN, Claire. Le problème du Haut-Karabagh. Slovo (Revue du Centre de Recherches Russes et Euro-Asiatiques), Paris, n. 7, p. 53-82, 1986.

OC MEDIA. Thousands of pro-war protesters rally in Azerbaijan. Open Caucasus Media, [s.l.], 15 July 2020. Available in: https://oc-media.org/thousands-of-prowar-protesters-rally-in-azerbaijan/. Access in: 22 Nov. 2020.

ONU. Conselho de Segurança. Resolução 884 aprovada pelo Conselho de Segurança na 3313a reunião em 12 de novembro de 1993. [New York]: ONU, 1993.

PAPAZIAN, Lalig. A people's will: Armenian irredentism over Nagorno-Karabagh. In: CHORBAJIAN, Levon (org,). The making of Nagorno-Karabagh: from secession to republic. New York: Palgrave Publishers, 2001, p. 54-94. 
A guerra de Nagorno-Karabakh: as disputas em torno dos conceitos de 'vítima' e 'genocídio'

PAPAZIAN, Taline. L’Arménie à l'épreuve du feu: forger l'État à travers la guerre. Paris: Éditions Karthala, 2016.

PIGS and Cows in the ruined and desecrated Aghdam Mosque. Reddit, [s.l.], 01 Mar. 2019, Available at:

https://www.reddit.com/r/azerbaijan/comments/aw7nbp/pigs_and_cows_in_the _ruined_and_desecrated_aghdam/. Access on: 22 Nov 2020.

POLLAK, Michael. Memória e identidade social. Estudos Históricos, Rio de Janeiro, n. 5, v. 10, p. 200-212, 1992.

PORTELLI, Alessandro. O massacre de Civitella Val di Chiana (Toscana, 29 de junho de 1944): mito e política, luto e senso comum. In: FERREIRA, Marieta de Moraes; AMADO, Janaína (org.). Usos \& abusos da história oral. Rio de Janeiro: Fundação Getúlio Vargas, 1996, p. 103-130.

PROFESSOR UNIVERSITÁRIO. [Entrevista concedida a] Pedro Bogossian Porto, Yerevan (Armênia), 18 mar. 2020. (Arquivo pessoal).

PROFESSORA UNIVERSITÁRIA. [Entrevista concedida a] Pedro Bogossian Porto, Yerevan (Armênia), 21 abr. 2016. (Arquivo pessoal).

RFE/RL. Tensions high along Armenia-Azerbaijan border after days of Skirmishes. Radio Free Europe/Radio Liberty. [S.L.], 17 July 2020. Available in: https://www.rferl.org/a/armenia-azerbaijan-tensions-border-skirmishesnuclear-plant/30733038.html. Access on: 22 Nov 2020.

SEGRILLO, Angelo. O Declínio da URSS: um estudo das causas. Rio de Janeiro: Record, 2000.

SMITH, Roger W. How does one address the 100th anniversary of the Armenian Genocide and modern denial? Genocide Studies International 10, Toronto, n. 1, p. 100-104, 2016.

SYNOVITZ, Ron. Are Syrian mercenaries helping Azerbaijan fight for NagornoKarabakh?" Radio Free Europe/Radio Liberty. [S.l.], 15 Oct. 2020. Available in: https://www.rferl.org/a/are-syrian-mercenaries-helping-azerbaijan-fight-fornagorno-karabakh-/30895331.html. Access on: 22 Nov. 2020.

STRONSKI, Paul. Behind the flare-up along Armenia-Azerbaijan border. Carnegie endowment for international peace. Washington, 22 July 2020. Available in: https://carnegieendowment.org/2020/07/22/behind-flare-up-along-armeniaazerbaijan-border-pub-82345. Access on: 22 Nov 2020.

TER MINASSIAN, Anahide. Histoires croisées: diaspora, Arménie, Transcaucasie. Marseille : Editions Parenthèses, 1997. 
TER MINASSIAN, Anahide. La République d'Arménie: 1918-1920. 2. ed. Bruxelas: Éd. Complexe, 2006.

THE INFORMATION CHECKING CENTER. Khojaly: myths and facts. [S.l.], 28 Feb. 2020. Available in: https://info check.am/en/posts/297. Access on: 18 Mar. 2021.

THE PRIME MINISTER OF REPUBLIC OF ARMENIA. Nikol Pashinyan attends opening of 7th pan-Armenian summer games. [S.l.], 05 Aug. 2019. Available in: https://www.primeminister.am/en/Artsakh-visits/item/2019/08/05/NikolPashinyan-visit-to-Artsakh/. Access on: 20 Mar 2021.

THE PRIME MINISTER OF REPUBLIC OF ARMENIA. That document does not envisage a substantive solution to the issue: only a cessation of hostilities. [S.l.], 12 Oct. 2020. Available in: https://www.primeminister.am/en/statements-andmessages/item/2020/11/12/Nikol-Pashinyan-Speech/. Access on: 22 Nov. 2020.

TROIANOVSKI, Anton. At front lines of a brutal war: death and despair in Nagorno-Karabakh. The New York Times. New York, 18 Oct. 2020. Available in: https://www.nytimes.com/2020/10/18/world/europe/Nagorno-Karabakh-warArmenia-Azerbaijan.html. Access on: 22 Nov. 2020.

Universidade do Estado de Santa Catarina - UDESC

Programa de Pós-Graduação em História - PPGH

Revista Tempo e Argumento Volume 13 - Número 32 - Ano 2021 tempoeargumento@gmail.com 